\title{
Effect of Garlic Paste Added to Yoghurt of Cow Milk
}

\author{
Mylvaganam Pagthinathan and Rajayogeswaran Tharmiga \\ Department of Animal Science, Faculty of Agriculture, Eastern University, Vantharumoolai, Chenkalady 30350, Sri Lanka
}

\begin{abstract}
Yoghurt has greater popularity among fermented milk products. The development of fruit and flavoured yoghurt resulted in this product of major importance in markets. Garlic is a common food spice and herbal medicine for preventing of many human diseases. This study was conducted to analyze physicochemical properties of yoghurt by incorporating of garlic paste at different concentrations. Yoghurt mixtures were prepared with $0.5 \%, 1 \%, 2 \%$ and $3 \%$ garlic paste, and without garlic paste as a control. They were subjected into chemical, sensorial and microbial assessment during the storage period of four weeks. At the first week, the chemical attributes, such as ash, dry matter, total sugar, reducing sugar and $\mathrm{pH}$ show significantly $(P<0.05)$ higher in $3 \%$ garlic added yoghurt. On the other hand, titrable acidity was higher in yoghurt made without garlic paste. At the fourth week of storage period, 3\% garlic added yoghurt received higher mean value for ash, dry matter, total sugar, reducing sugar and $\mathrm{pH}$. Similarly, yoghurt made without garlic received higher mean value for titrable acidity. Garlic reduced the bacterial load in the yoghurt, as bacterial count was decreased with increase in the concentration of garlic paste. Finally, organoleptic assessment revealed that there were $(P<0.05)$ changes among the treatments in the sensory attributes. Although, yoghurt made from $1 \%$ of garlic at the first week of storage showed the best overall acceptability compared with other all treatments, such as values of ash, dry matter, total sugar and reducing sugar were $0.61 \% \pm 0.05 \%, 14.73 \% \pm 3 \%, 12.7 \% \pm 1.57 \%$ and $1.86 \% \pm 0.19 \%$, respectively.
\end{abstract}

Key words: Garlic paste, overall acceptability, nutritional quality, yoghurt.

\section{Introduction}

Milk and fermented milk products have long history of use, and consumption of dairy products has increased in the recent past years due to the good dietary and properties. There has been an unbelievable increase in the production of fermented milk and products in developed countries and most of the increase is attributed to the health benefits [1].

One of the most traditional cultured milk is the yoghurt, which is produced by addition of starter culture containing Streptococcus thermophilus and Lactobacillus delbrueckii subsp. bulgaricus. Human consumption of yoghurt has been associated with tremendous health benefits, as it has been improving the gastrointestinal functions and reduction of human diseases [2, 3]. Lactic acids bacteria present in the yoghurt is beneficial on human health, including protection against gastrointestinal problem, enhancing

Corresponding author: Mylvaganam Pagthinathan, Ph.D., research fields: dairy processing technology, reproductive physiology of cattle and buffalo. the digestion of lactose, decreasing risk of cancer, lowering blood cholesterol and improving immune response $[4,5]$.

Garlic is a frost-hardy bulbous perennial erect herb, and it has long been taken as a tonic, a bactericide and a popular remedy for various disorders [6, 7]. More recently, garlic has been recognized as a common food spice and herbal medicine for the prevention and the treatment of a variety of diseases, like infectious diseases and heart diseases [8]. In addition, it is used to prevent many of chronic diseases associated with old age, such as stroke, cancer, arthritis, cataract formation and in promoting general health by increasing energy levels and general blood circulation [7,9]. Further, garlic has been considered as a rich source of carbohydrate, proteins and phosphorus. Ascorbic acid contents are reported to be very high in green garlic [7]. The information on making of yoghurt using garlic paste is lacking. Therefore, this study was designed to make yoghurt by incorporation of different concentrations of garlic paste and to assess the 
physicochemical and microbial properties during the storage of yoghurt.

\section{Materials and Methods}

The study was conducted at Department of Animal Science Laboratory, Faculty of Agriculture, Eastern University, Sri Lanka. Milk was collected from the Livestock Farm, Faculty of Agriculture, Eastern University, Sri Lanka throughout the study period.

\subsection{Preparation of Garlic Paste}

Sheath removed garlic cloves were sterilized by distilled water for $5 \mathrm{~min}$. They were boiled and grated with same amount of distilled water and made garlic paste.

\subsection{Yoghurt Preparation}

Skim milk was prepared by using cream separator. Then the milk was pasteurized $65^{\circ} \mathrm{C}$ for $30 \mathrm{~min}$, and milk temperature was gradually declined at this time, meanwhile sugar and gelatine (stabilizer) were added and cooled to $37{ }^{\circ} \mathrm{C}$. Then this milk was inoculated with a commercial yoghurt culture (freeze-dried lactic culture for direct vat set). Then garlic paste was added to milk mixture at the basis of $0 \%, 0.5 \%, 1 \%, 2 \%$ and $3 \%$ of total weight. Then, flavors and coloring were added and mixed well. Then mixture of inoculated milk was poured into plastic containers, and incubated at $40{ }^{\circ} \mathrm{C}$ for overnight. The yoghurt samples were stored in a refrigerator at about $4-5{ }^{\circ} \mathrm{C}$ for analysis at week 1 , week 2 , week 3 and week 4 of storage.

\subsection{Nutritional Composition Analysis}

Yoghurt samples were subjected to nutritional analysis to determine the nutritional composition of yoghurt, such as fat, total dry matter, ash content and moisture. These yoghurt samples were analyzed in triplicate for moisture by oven drying at $105^{\circ} \mathrm{C}$ to get constant weight according to AOAC method [10] and percentage of moisture was calculated as Eq. (1):

Moisture $(\%)=100 \%-$ total solid $(\%)$
Ash content was determined by using muffle furnace at $550{ }^{\circ} \mathrm{C}$ for $4 \mathrm{~h}$. The fat content of cheese was determined by the Gerber method [11]. Total sugar and reducing sugar were determined by Lane and Eynon method. The titrable acidity was determined by titrating with $0.1 \mathrm{~N} \mathrm{NaOH}$.

\subsection{Measurement of $\mathrm{pH}$}

The yoghurt $\mathrm{pH}$ was determinate by blending $5 \mathrm{~g}$ of grated yoghurt with $5 \mathrm{~mL}$ of deionizer water [12]. The $\mathrm{pH}$ was measured by a digital $\mathrm{pH}$ meter (model: Delta $320 \mathrm{pH}$ meter) after calibration with fresh $\mathrm{pH} 4.0$ and 7.0 stranded buffer.

\subsection{Syneresis}

Degree of synersis, expressed as portion of free whey, was measured by a small modification of method by Al-Kadamany et al. [13]. Yoghurt sample was placed on a filter paper resting on a top of a funnel. After $0.5 \mathrm{~h}$ and $2 \mathrm{~h}$ of drainage, the quantity of whey was weighed and synersis was calculated as Eq. (2):

$$
\begin{aligned}
& \text { Syneresis percentage }= \\
& \frac{\text { liquid weight }(\mathrm{g})}{\text { initial weight of yoghurt sample }(\mathrm{g})} \times 100
\end{aligned}
$$

\subsection{Sensory Evaluation}

In sensory evaluation, the samples were subjected to five-point hedonic scale test, and the acceptability of samples was judged by 30 untrained members to determine consumer preference as described by Resurreccion [14]. The sensory characteristics, such as colour, flavour, taste, texture and overall acceptability of the yoghurt samples were judged by the panelists at day 1 , week 1 , week 2 , week 3 and week 4 of storage period.

\subsection{Microbial Analysis}

Bacterial colonic counts were carried out at days 14 and 28 in three replicates of each sample. Samples (1 g) were diluted with $0.1 \%$ sterile peptonated water $(9$ 
$\mathrm{mL}$ ). Afterwards, serial dilutions were carried out, and bacteria were counted, applying the pour plate technique colony forming unit [15]. Bacterial colonies were enumerated in nutrient agar with sheep blood under aerobic incubation at $37{ }^{\circ} \mathrm{C}$ for $48 \mathrm{~h}$. All bacterial colonies were counted using colony counter with stranded procedure.

\subsection{Statistical Analysis}

Data obtained in chemical analysis were subjected to analysis of variance (ANOVA) and mean separation was done with Duncan's multiple range test (DMRT). Descriptive statistics was done on sensory attributes and the means were compared using the Tukey's test $(P<0.05)$.

\section{Results and Discussion}

3.1 Nutritional Attributes, $p H$ and Syneresis of Yoghurts Made from Different Concentration of Garlic Paste at Day 1

The nutritional attributes of yoghurt made from different concentration of garlic paste are given in Table 1. The results have shown that ash contents, dry matter contents, total sugar, reducing sugar and syneresis did not show any significant changes among concentration at day 1 . It might be due to that considerable amount of changes not occurred in biochemical and microbial reactions. At day 1 , titrable acidity was lower in $3 \%$ garlic added yoghurt $(0.22 \%)$ and higher in yoghurt without garlic $(0.34 \% \pm 0.03 \%)$. The $\mathrm{pH}$ was the highest in 3\% garlic added yoghurt $(4.88 \pm 0.01)$ and the lowest in yoghurt without garlic $(4.80 \pm 0.04)$. This may be due to the concentration of garlic.

\subsection{Changes of Nutritional Attributes and $\mathrm{pH}$ of Yoghurt during Storage Period}

3.2.1 Ash Contents in Yoghurt during the Storage Period

Ash content is an indicator of total amount of minerals present in the yoghurt. As shown in Table 2, at the first week of storage, $3 \%$ garlic added yoghurt exhibited $(P<0.05)$ higher mean value $(0.73 \% \pm$ $0.08 \%)$ than yoghurt made from without garlic $(0.56 \%$ $\pm 0.04 \%)$. At the fourth week of storage, $3 \%$ garlic added yoghurt also showed higher mean value $(0.97 \%$ $\pm 0.04 \%$ ), and yoghurt made without garlic received lower mean value $(0.79 \% \pm 0.04 \%)$. It could be due to that addition of higher concentration of garlic paste increases the ash contents in yoghurt. This study also revealed that ash content varied between $0.56 \%$ and $0.97 \%$, and this value increased during storage period. The results agree with the finding of Alam et al. [16], who reported that the average ash contents of $1.12 \%$ found in yoghurt made in laboratory and available in the market. Qureshi et al. [7] also found that the ash percentage of all yoghurt samples increased during 15 $\mathrm{d}$ of storage period.

Table 1 Nutrition, pH and syneresis status of yoghurts made from different concentration of garlic at day 1.

\begin{tabular}{llllll}
\hline \multirow{2}{*}{ Attributes } & \multicolumn{5}{c}{ Treatments } \\
\cline { 2 - 6 } & $\mathrm{T}_{0}$ & $\mathrm{~T}_{1}$ & $\mathrm{~T}_{2}$ & $\mathrm{~T}_{3}$ & $\mathrm{~T}_{4}$ \\
\hline Ash (\%) & $0.53 \pm 0.01^{\mathrm{a}}$ & $0.57 \pm 0.24^{\mathrm{a}}$ & $0.58 \pm 0.06^{\mathrm{a}}$ & $0.63 \pm 0.03^{\mathrm{a}}$ & $0.66 \pm 0.07^{\mathrm{a}}$ \\
Dry matter (\%) & $19.40 \pm 3.85^{\mathrm{a}}$ & $22.26 \pm 1.12^{\mathrm{a}}$ & $23.25 \pm 1.63^{\mathrm{a}}$ & $23.30 \pm 1.05^{\mathrm{a}}$ & $23.60 \pm 0.06^{\mathrm{a}}$ \\
Total sugar (\%) & $12.73 \pm 1.57^{\mathrm{a}}$ & $12.83 \pm 0.91^{\mathrm{a}}$ & $12.96 \pm 0.24^{\mathrm{a}}$ & $13.84 \pm 0.00^{\mathrm{a}}$ & $14.70 \pm 1.2^{\mathrm{a}}$ \\
Reducing sugar (\%) & $1.99 \pm 0.00^{\mathrm{a}}$ & $2.03 \pm 0.06^{\mathrm{a}}$ & $2.17 \pm 0.13^{\mathrm{a}}$ & $2.18 \pm 0.11^{\mathrm{a}}$ & $2.33 \pm 0.58^{\mathrm{a}}$ \\
Titrable acidity (\%) & $0.34 \pm 0.03^{\mathrm{a}}$ & $0.31 \pm 0.02^{\mathrm{ab}}$ & $0.27 \pm 0.07^{\mathrm{ab}}$ & $0.26 \pm 0.05^{\mathrm{ab}}$ & $0.22 \pm 0.00^{\mathrm{b}}$ \\
pH & $4.80 \pm 0.04^{\mathrm{b}}$ & $4.83 \pm 0.03^{\mathrm{ab}}$ & $4.86 \pm 0.01^{\mathrm{ab}}$ & $4.87 \pm 0.01^{\mathrm{a}}$ & $4.88 \pm 0.01^{\mathrm{a}}$ \\
Syneresis (\%) & $47.78 \pm 1.56^{\mathrm{a}}$ & $47.66 \pm 0.68^{\mathrm{a}}$ & $46.64 \pm 0.74^{\mathrm{a}}$ & $45.46 \pm 2.26^{\mathrm{a}}$ & $45.17 \pm 1.41^{\mathrm{a}}$ \\
\hline
\end{tabular}

$\mathrm{T}_{0}$ : yoghurt without garlic; $\mathrm{T}_{1}: 0.5 \%$ garlic added yoghurt; $\mathrm{T}_{2}: 1 \%$ garlic added yoghurt; $\mathrm{T}_{3}: 2 \%$ garlic added yoghurt; $\mathrm{T}_{4}: 3 \%$ garlic added yoghurt. Means followed by different letters in each column were significantly different based on DMRT $(P<0.05)$. 
Table 2 Ash and dry matter content in yoghurt during storage period.

\begin{tabular}{llllll}
\hline Treatment & Attributes & Week 1 & Week 2 & Week 3 & Week 4 \\
\hline \multirow{2}{*}{$\mathrm{T}_{0}$} & Ash (\%) & $0.56 \pm 0.04^{\mathrm{e}}$ & $0.66 \pm 0.21^{\text {cde }}$ & $0.74 \pm 0.21^{\text {abcde }}$ & $0.79 \pm 0.04^{\text {abcde }}$ \\
& Dry matter (\%) & $10.65 \pm 3.73^{\mathrm{f}}$ & $16.8 \pm 2.05^{\text {de }}$ & $18.01 \pm 1.18^{\text {cde }}$ & $19.62 \pm 0.17^{\mathrm{abcde}}$ \\
\hline \multirow{2}{*}{$\mathrm{T}_{1}$} & Ash (\%) & $0.59 \pm 0.22^{\mathrm{e}}$ & $0.68 \pm 0.00^{\text {bcde }}$ & $0.76 \pm 0.03^{\text {abcde }}$ & $0.82 \pm 0.23^{\text {abcde }}$ \\
& Dry matter (\%) & $14.73 \pm 3.80^{\text {ef }}$ & $16.8 \pm 2.05^{\text {de }}$ & $19.66 \pm 0.68^{\text {abcde }}$ & $19.75 \pm 0.4^{\text {abcd }}$ \\
\hline \multirow{2}{*}{$\mathrm{T}_{2}$} & Ash (\%) & $0.61 \pm 0.05^{\text {de }}$ & $0.71 \pm 0.11^{\text {abcde }}$ & $0.81 \pm 0.17^{\text {abcde }}$ & $0.91 \pm 0.06^{\text {abc }}$ \\
& Dry matter (\%) & $14.73 \pm 3.80^{\text {ef }}$ & $18.23 \pm 0.55^{\text {bcde }}$ & $20.89 \pm 0.22^{\text {abcd }}$ & $22.30 \pm 0.28^{\text {abc }}$ \\
\hline \multirow{2}{*}{$\mathrm{T}_{3}$} & Ash (\%) & $0.65 \pm 0.04^{\text {cde }}$ & $0.74 \pm 0.10^{\text {abcde }}$ & $0.85 \pm 0.01^{\text {abcd }}$ & $0.94 \pm 0.05^{\text {ab }}$ \\
\hline \multirow{2}{*}{$\mathrm{T}_{4}$} & Dry matter (\%) & $18.53 \pm 4.10^{\text {abcde }}$ & $20.02 \pm 1.52^{\text {abcd }}$ & $21.17 \pm 0.79^{\text {abcd }}$ & $23.05 \pm 0.08^{\text {ab }}$ \\
\hline
\end{tabular}

$\mathrm{T}_{0}$ : yoghurt without garlic; $\mathrm{T}_{1}: 0.5 \%$ garlic added yoghurt; $\mathrm{T}_{2}: 1 \%$ garlic added yoghurt; $\mathrm{T}_{3}: 2 \%$ garlic added yoghurt; $\mathrm{T}_{4}: 3 \%$ garlic added yoghurt. Means followed by different letters in each column were significantly different based on DMRT $(P<0.05)$.

3.2.2 Dry Matter Contents in Yoghurt during the Storage Period

The increasing trend of dry matter content was observed with storage period (Table 2). Moreover, it was observed that the dry matter content of yoghurt made with garlic paste were slightly higher than yoghurt made without garlic paste. Yoghurt added with $3 \%$ garlic obtained higher mean value $(23.49 \% \pm$ $0.12 \%)$ than yoghurt made without garlic $(19.62 \% \pm$ $0.17 \%$ ) at the fourth week of storage. Similar results were supported by Gundoğdu et al. [3], who reported that adding of garlic concentration increased the dry matter contents of food product.

\subsubsection{Total Sugar and Reducing Sugar}

The result showed that total sugar and reducing sugar was $(P<0.05)$ decreased throughout the storage period (Table 3). It might be due to the conversion of lactose into lactic acid with time of storage. At the fourth week of storage period, 3\% garlic added yoghurt has significantly $(P<0.05)$ higher amount of total sugar $(12.60 \% \pm 1.75 \%)$ and reducing sugar $(1.55 \% \pm 0.09 \%)$. On the other hand, yoghurt made from without garlic has lower value of total sugar $(10.29 \% \pm 0.21 \%)$ and reducing sugar $(1.23 \% \pm$ $0.06 \%$ ) at the fourth week of storage. This may be due to the hydrolysis of polysaccharides oxidation of sugars present in yoghurt. These findings are in agreement with Goodenought and Kleyn [17], who reported that the decrease in lactose content during one month of storage is due to production of lactic acid.

\subsubsection{Titrable Acidity}

Titrable acidity was significantly $(P<0.05)$ increased during the storage period (Table 4). At the fourth week of storage period, titrable acidity was significantly $(P<0.05)$ higher in yoghurt made without garlic paste $(0.50 \% \pm 0.0 \%)$ than yoghurt made from $3 \%$ garlic paste added $(0.36 \% \pm 0.06 \%)$. The changes in titrable acidity of yoghurt could be a fermentation process by microorganism and degradation of lactose into lactic acid. These results are in agreement with the results of Nwachukwu and Ezejiaku [18], who reported the decrease of the titrable acidity with increasing the amount of garlic added. The present study also coincides with the results of Gundoğdu et al. [3], who found out that titrable acidity of garlic added yoghurt samples was increased during storage due to the use of lower garlic ratio.

\section{$3.2 .5 \mathrm{pH}$}

The $\mathrm{pH}$ decreased during the storage period. The changes in $\mathrm{pH}$ may due to the formation of lactic acid during fermentation process by microorganism. During the first week of storage, $\mathrm{pH}$ significantly $(P<$ $0.05)$ varied among the treatments. However, yoghurt made without garlic paste received the lowest mean value $(4.71 \pm 0.02)$ than $3 \%$ garlic added yoghurt $(4.87 \pm 0.06)$ at the first week of storage. At the fourth 
Table 3 Total sugar and reducing sugar in yoghurt during storage period.

\begin{tabular}{|c|c|c|c|c|c|}
\hline Treatment & Attributes & Week 1 & Week 2 & Week 3 & Week 4 \\
\hline \multirow{2}{*}{$\mathrm{T}_{0}$} & Total sugar (\%) & $12.37 \pm 1.06^{\mathrm{abcd}}$ & $11.88 \pm 0.37^{\mathrm{abcd}}$ & $11.49 \pm 0.18^{\mathrm{bcd}}$ & $10.29 \pm 0.21^{\mathrm{d}}$ \\
\hline & Reducing sugar (\%) & $1.71 \pm 0.20^{\mathrm{abcd}}$ & $1.62 \pm 0.07^{\mathrm{bcde}}$ & $1.45 \pm 0.17^{\text {defg }}$ & $1.23 \pm 0.06^{\mathrm{g}}$ \\
\hline \multirow{2}{*}{$\mathrm{T}_{1}$} & Total sugar (\%) & $12.55 \pm 1.31^{\mathrm{abcd}}$ & $12.29 \pm 0.21^{\mathrm{abcd}}$ & $11.90 \pm 0.40^{\mathrm{abcd}}$ & $10.33 \pm 0.15^{\mathrm{d}}$ \\
\hline & Reducing sugar (\%) & $1.84 \pm 0.21^{\mathrm{abc}}$ & $1.70 \pm 0.04^{\mathrm{abcd}}$ & $1.47 \pm 0.14^{\mathrm{defg}}$ & $1.26 \pm 0.02^{\mathrm{fg}}$ \\
\hline \multirow{2}{*}{$\mathrm{T}_{2}$} & Total sugar (\%) & $12.73 \pm 1.57^{\mathrm{abc}}$ & $12.55 \pm 1.31^{\mathrm{abcd}}$ & $12.21 \pm 0.83^{\mathrm{abcd}}$ & $11.36 \pm 0.68^{\mathrm{cd}}$ \\
\hline & Reducing sugar (\%) & $1.86 \pm 0.19^{\mathrm{abc}}$ & $1.70 \pm 0.04^{\mathrm{abcd}}$ & $1.47 \pm 0.14^{\mathrm{defg}}$ & $1.29 \pm 0.02^{\mathrm{fg}}$ \\
\hline \multirow{2}{*}{$\mathrm{T}_{3}$} & Total sugar (\%) & $13.66 \pm 0.26^{\mathrm{ab}}$ & $12.96 \pm 0.24^{\mathrm{abc}}$ & $12.29 \pm 0.21^{\mathrm{abcd}}$ & $12.16 \pm 0.03^{\mathrm{abcd}}$ \\
\hline & Reducing sugar (\%) & $1.97 \pm 0.02^{\mathrm{a}}$ & $1.78 \pm 0.30^{\mathrm{abcd}}$ & $1.53 \pm 0.13^{\text {cdefg }}$ & $1.32 \pm 0.02^{\mathrm{efg}}$ \\
\hline \multirow{2}{*}{$\mathrm{T}_{4}$} & Total sugar (\%) & $14.04 \pm 0.28^{\mathrm{a}}$ & $13.47 \pm 0.00^{\mathrm{abc}}$ & $13.01 \pm 2.32^{\mathrm{abc}}$ & $12.6 \pm 1.75^{\mathrm{abc}}$ \\
\hline & Reducing sugar (\%) & $2.01 \pm 0.22^{\mathrm{a}}$ & $1.93 \pm 0.00^{\mathrm{ab}}$ & $1.58 \pm 0.13^{\text {cdef }}$ & $1.55 \pm 0.09^{\text {cdefg }}$ \\
\hline
\end{tabular}

$\mathrm{T}_{0}$ : yoghurt without garlic; $\mathrm{T}_{1}: 0.5 \%$ garlic added yoghurt; $\mathrm{T}_{2}: 1 \%$ garlic added yoghurt; $\mathrm{T}_{3}: 2 \%$ garlic added yoghurt; $\mathrm{T}_{4}: 3 \%$ garlic added yoghurt. Means followed by different letters in each column were significantly different based on DMRT $(P<0.05)$.

Table 4 pH and titrable acidity change in yoghurt during storage period.

\begin{tabular}{|c|c|c|c|c|c|}
\hline Treatment & Attributes & Week 1 & Week 2 & Week 3 & Week 4 \\
\hline \multirow{2}{*}{$\mathrm{T}_{0}$} & Titrable acidity $(\%)$ & $0.38 \pm 0.03^{\text {bcde }}$ & $0.42 \pm 0.02^{\mathrm{bc}}$ & $0.47 \pm 0.05^{\mathrm{ab}}$ & $0.50 \pm 0.00^{\mathrm{a}}$ \\
\hline & $\mathrm{pH}$ & $4.71 \pm 0.02^{\mathrm{c}}$ & $4.60 \pm 0.03^{\mathrm{d}}$ & $4.32 \pm 0.01^{\mathrm{e}}$ & $4.00 \pm 0.02^{\mathrm{a}}$ \\
\hline \multirow{2}{*}{$\mathrm{T}_{1}$} & Titrable acidity $(\%)$ & $0.33 \pm 0.05^{\text {defg }}$ & $0.36 \pm 0.0^{\text {cdef }}$ & $0.42 \pm 0.02^{\mathrm{bc}}$ & $0.47 \pm 0.05^{\mathrm{ab}}$ \\
\hline & $\mathrm{pH}$ & $4.77 \pm 0.02^{\mathrm{abc}}$ & $4.75 \pm 0.01^{\mathrm{bc}}$ & $4.58 \pm 0.01^{\mathrm{d}}$ & $4.55 \pm 0.03^{\mathrm{d}}$ \\
\hline \multirow{2}{*}{$\mathrm{T}_{2}$} & Titrable acidity $(\%)$ & $0.29 \pm 0.00^{\mathrm{ef}}$ & $0.33 \pm 0.05^{\mathrm{efg}}$ & $0.38 \pm 0.03^{\text {bcde }}$ & $0.42 \pm 0.02^{\mathrm{bc}}$ \\
\hline & $\mathrm{pH}$ & $4.84 \pm 0.09^{\mathrm{ab}}$ & $4.77 \pm 0.09^{\mathrm{abc}}$ & $4.74 \pm 0.07^{\mathrm{bc}}$ & $4.57 \pm 0.06^{\mathrm{d}}$ \\
\hline \multirow{2}{*}{$\mathrm{T}_{3}$} & Titrable acidity $(\%)$ & $0.27 \pm 0.03^{\mathrm{g}}$ & $0.31 \pm 0.08^{\mathrm{efg}}$ & $0.36 \pm 0.00^{\text {cdef }}$ & $0.40 \pm 0.05^{\mathrm{bcd}}$ \\
\hline & $\mathrm{pH}$ & $4.85 \pm 0.03^{\mathrm{ab}}$ & $4.77 \pm 0.02^{\mathrm{abc}}$ & $4.76 \pm 0.01^{\mathrm{abc}}$ & $4.75 \pm 0.01^{\mathrm{bc}}$ \\
\hline \multirow{2}{*}{$\mathrm{T}_{4}$} & Titrable acidity $(\%)$ & $0.25 \pm 0.00^{\mathrm{g}}$ & $0.27 \pm 0.03^{\mathrm{g}}$ & $0.32 \pm 0.00^{\text {defg }}$ & $0.36 \pm 0.06^{\text {cdef }}$ \\
\hline & $\mathrm{pH}$ & $4.87 \pm 0.06^{\mathrm{a}}$ & $4.84 \pm 0.01^{\mathrm{ab}}$ & $4.80 \pm 0.02^{\mathrm{abc}}$ & $4.78 \pm 0.01^{\mathrm{abc}}$ \\
\hline
\end{tabular}

$\mathrm{T}_{0}$ : yoghurt without garlic; $\mathrm{T}_{1}: 0.5 \%$ garlic added yoghurt; $\mathrm{T}_{2}: 1 \%$ garlic added yoghurt; $\mathrm{T}_{3}: 2 \%$ garlic added yoghurt; $\mathrm{T}_{4}: 3 \%$ garlic added yoghurt. Means followed by different letters in each column were significantly different based on DMRT $(P<0.05)$.

week of storage, 3\% garlic added yoghurt showed higher mean value $(4.78 \pm 0.01)$ compared to other treatments. These results agree with results reported by Behrad et al. [19], who mentioned that the $\mathrm{pH}$ for all yoghurts reduced from the initial values of 4.5 to 4.09 at $28 \mathrm{~d}$ of storage.

\subsection{Effect of Storage on Sensorial Attributes at Different Treated Yoghurt Samples}

The mean values of sensory attributes for the treatments were analyzed. Results showed that there were significant $(P<0.05)$ variations among the treatments for all attributes, such as texture, taste, flavour, colour and overall acceptability. All attributes were decreased during the storage period in all kinds of yoghurt. Yoghurt made with 1\% garlic paste showed higher mean value than yoghurt made with $3 \%$ garlic paste for texture, taste, colour and flavour at the fourth week of storage. Garlic (1\%) added yoghurt had higher degree of overall acceptability and gained the highest scores for taste, flavour, texture and colour at the first week of storage. Yoghurt with $0.5 \%$ of garlic paste showed the second high mean value and the lowest mean value was obtained in $3 \%$ garlic paste added yoghurt, indicating that most of panelists did not prefer $3 \%$ garlic paste added yoghurt at any point of storage period. Based on the sensory analysis, the majority of panelist prefer yoghurt with $1 \%$ of garlic paste at the first week of storage, which exhibited values for ash, dry matter, total sugar and reducing sugar 


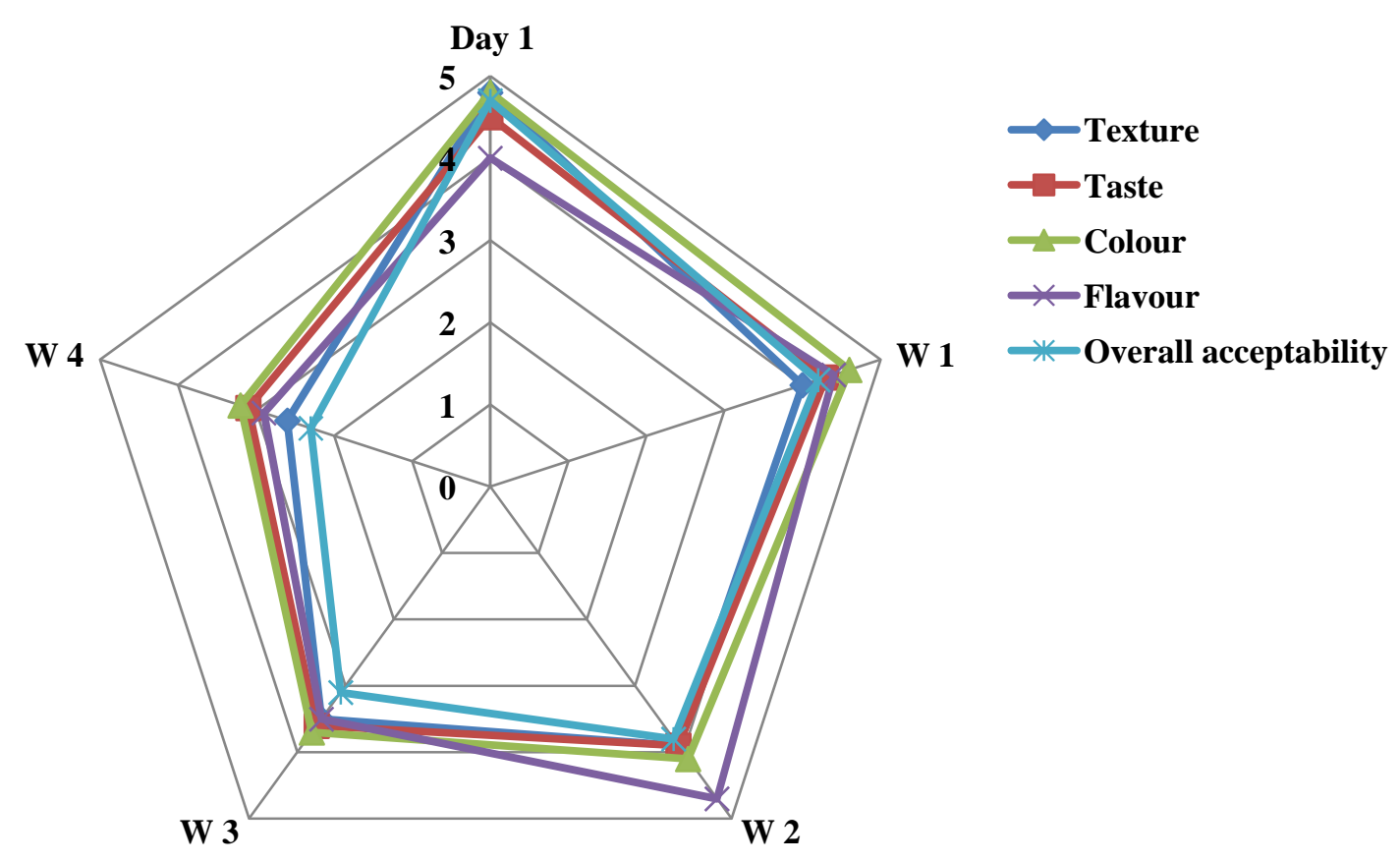

Fig. 1 Changes of sensory attributes of $1 \%$ garlic paste added yoghurt during day 1, week 1, week 2 , week 3 and week 4 storage in a refrigerator at about $4-5{ }^{\circ} \mathrm{C}$.

Table 5 Microbial count at two weeks interval of storage period.

\begin{tabular}{lll}
\hline Treatments & Week 2 (CFU/mL) & Week 4 (CFU/mL) \\
\hline $\mathrm{T}_{0}$ & $5.4 \times 10^{5 \mathrm{a}}$ & $3.0 \times 10^{5 \mathrm{a}}$ \\
$\mathrm{T}_{1}$ & $4.75 \times 10^{5 \mathrm{~b}}$ & $2.5 \times 10^{5 \mathrm{~b}}$ \\
$\mathrm{~T}_{2}$ & $3.6 \times 10^{5 \mathrm{c}}$ & $2.3 \times 10^{5 \mathrm{bc}}$ \\
$\mathrm{T}_{3}$ & $3.0 \times 10^{5 \mathrm{~d}}$ & $2.0 \times 10^{5 \mathrm{bc}}$ \\
$\mathrm{T}_{4}$ & $2.35 \times 10^{5 \mathrm{e}}$ & $1.95 \times 10^{5 \mathrm{c}}$ \\
\hline
\end{tabular}

$\mathrm{T}_{0}$ : yoghurt without garlic; $\mathrm{T}_{1}: 0.5 \%$ garlic added yoghurt; $\mathrm{T}_{2}$ : $1 \%$ garlic added yoghurt; $\mathrm{T}_{3}: 2 \%$ garlic added yoghurt; $\mathrm{T}_{4}: 3 \%$ garlic added yoghurt. Means followed by different letters in each column were significantly different based on DMRT $(P<$ $0.05)$.

were $0.61 \% \pm 0.05 \%, 14.73 \% \pm 3 \%, 12.7 \% \pm 1.57 \%$ and $1.86 \% \pm 0.19 \%$, respectively at the first week of storage (Fig. 1).

\subsection{Effect of Storage on Bacterial Load of Different Treated Yoghurt Samples}

Bacteriological study revealed that the yoghurt made without garlic showed remarkably higher bacterial colony forming unit than the yoghurt made with garlic paste during the storage period (Table 5). Garlic influenced the bacterial growth in yoghurt, and bacterial colony forming unit count was decreased with increase in the concentration of garlic paste. Garlic (3\%) added yoghurt showed the lowest bacterial colony forming unit at the storage period. It might be due to bacterial degradation in the yoghurt.

\section{Conclusions}

Chemical parameters of garlic added yoghurt, such as ash, dry matter and titrable acidity, were increased with storage period. Total sugar and reducing sugar were decreased with storage period. $\mathrm{pH}$ also showed reduction with storage period. Yoghurt without garlic paste showed higher amount of colony forming unit than garlic paste added yoghurt. Sensory attributes, such as texture, taste, flavour, colour and overall acceptability, varied among the different types of yoghurt. Finally, the majority of panelist preferred yoghurt made from $1 \%$ of garlic paste than other types 
of yoghurt.

\section{Acknowledgments}

The authors wish to thank Eastern University, Sri Lanka for financial support.

\section{References}

[1] Vali, C., and Traill, W. B. 2005. "Culture and Food: A Model of Yoghurt Consumption in the EU." Food Qual. Prefer. 16 (4): 291-304.

[2] Birollo, G. A., Reinheimer, J. A., and Vinderola, C. G. 2000. "Viability of Lactic Acid Microflora in Different Types of Yogurt." Food. Res. Int. 33 (9): 799-805.

[3] Gundoğdu, E., Cakmakci, S., and Dağdemir, E. 2009. "The Effect of Garlic (Allium sativum L.) on Some Quality Properties and Shelf-Life of Set and Stirred Yoghurt.” Turkey J. Vet. Anim. Sci. 33 (1): 27-35.

[4] Schrezenmeir, J., and De Vrese, M. 2001. "Probiotics, Prebiotics and Synbiotics-Approaching a Definition." Am. J. Clin. Nutr. 73 (2): 361-4.

[5] Donkora, O. N., Henrikssonb, A., Vasiljevica, T., and Shaha, N. P. 2006. "Effect of Acidification on the Activity of Probiotics in Yoghurt during Cold Storage." Int. Dairy. J. 16 (10): 1181-9.

[6] Blackwood, J., and Fulder, S. 1986. Garlic: Nature's Original Remedy. England: Javelin Books.

[7] Qureshi, A. M., Hassan, S. Y., Sulariya, A. M., and Rashid, A. A. 2011. "Preparation and Nutritional Evaluation of Garlic Based Yogurt." Sci. Int. (Lahore) 23 (1): 59-62.

[8] Fogarty, M. 1993. "Garlic's Potential Role in Reducing Heart Disease.” Br. J. Clin. Pract. 47 (2): 64-5.

[9] Vita, J. A., and Keaney, J. F. 2002. "Endothelial Functions: A Barometer for Cardiovascular Risk." Circulation 106 (6): 640-2.

[10] Association of Official Analytical Chemists (AOAC). 1990. AOAC Official Methods of Analysis, 15th ed.. Vol.
2, Arlington, VA: AOAC.

[11] National Dairy Research Institute (NDRI). 1972. "Determination of Fat in Cheese Evaporated and Condensed Milks by Gerber Method." In Manual in Dairy Chemistry. Bangalore, India: NDRI, 64-5.

[12] Patel, H. G., Upadhyay, K. G., Miyani, R. V., and Pandya, A. J. 1993. "Instron Texture Profile of Buffalo Milk Cheddar Cheese as Influenced by Composition and Ripening Changes." Food Qual. Prefer. 4 (4): 187-92.

[13] Al-Kadamany, E., Khattar, M., Haddad, T., and Toufeili, I. 2003. "Estimation of Shelf Life of Concentrated Yoghurt by Monitoring Selected Microbiological and Physiological Changes during Storage." Lebensmittel-Wissenschaft \& Technologie 36: 407-14.

[14] Resurreccion, A. V. A. 1998. Consumer Sensory Testing for Product Development. Gaithersburg: Aspen Publications Inc..

[15] Kodaka, H., Mizuochi, S., Teramura, H., and Nirazuka, T. 2005. "Comparison of the Compact Dry TC Method with the Standard Pour Plate Method (AOAC Official Method 966.23) for Determining Aerobic Colony Counts in Food Samples." J. AOAC. Int. 88 (6): 1702-13.

[16] Alam, M. J., Ali, M. Y., Islam, M. A., and Islam, M. N. 2002. "Quality of Yogurt (Dahi) made in Laboratory and Available in the Market of Mymensingh Town in Bangladesh.” Pak. J .Biol. Sci. 5 (3): 343-5.

[17] Goodenought, E. R., and Kleyn, D. H. 1976. "Qualitative and Quantitative Changes in Carbohydrates during the Manufacture of Yoghurt.” J. Dairy Sci. 59 (1): 45-7.

[18] Nwachukwu, E., and Ezejiaku, F. C. 2014. "Microbial and Physicochemical Characteristics of Locally Produced Pineapple Juice Treated with Garlic and Ginger." Int. J. Curr. Microbiol. App. Sci. 3 (6): 895-901.

[19] Behrad, S., Yusof, M. Y., Goh, K. L., and Baba, A. S. 2009. "Manipulation of Probiotics Fermentation of Yogurt by Cinnamon and Licorice: Effects on Yogurt Formation and Inhibition of Helicobacter Pylori Growth in Vitro." World Acad. Sci. Eng. Technol. 60: 590-4. 